\title{
APLIKASI KEAMANAN PINTU BERBASIS ARDUINO UNO R3 ATMEGA 328P MENGGUNAKAN FINGERPRINT DAN ULTRASONIK
}

\author{
Hendi Setiawan ${ }^{1}$, Darmawan Mega Permana ${ }^{2}$, Agus Fitro Handoko ${ }^{3}$ \\ ${ }^{1,2,3}$ Sekolah Tinggi Teknologi Indonesia Tanjungpinang \\ Jln. Poma Air No. 28 Tanjungpinang Kepulauan Riau Indonesia \\ ${ }^{1}$ hendi@sttindonesia.ac.id \\ 2darmawan_mega05@yahoo.com \\ 3agusfitoh13@gmail.com
}

\begin{abstract}
Intisari- Dalam sistem keamanan pintu memang sudah banyak yang menggunakan, bahakan lebih canggih, namun dengan kecanggihan atau sistem keamanannya lebih baik tetapi terdapat juga kekurangannya, yaitu biaya untuk menginplementasikannya sangatlah mahal. Oleh karna itu dibutuhkanlah sebuah sistem keamanan pintu yang lebih murah dan terjangkau dalam pengimplementasiannya. Dalam penelitian ini penulis mengangkat sebuah kasus yaitu membuat sebuah sistem keamanan pintu yang dapat diterapkan dan terjangkau dalam biaya oprsasionalnya. Sistem keamanan pintu ini menggunakan aplikasi arduino sebagai uploader, kemudian sensor fingerprint dan sensor ultrasonik sebagai alat yang digunakan. Sistem keamanan pintu ini hanya dapat di implementasikan jika sistem ini mendapat suplay arus listrik dan hanya dapat diakses terhadap sidik jari yang sudah terdaftar.

Kata kunci-Sistem Keamanan Pintu, Aplikasi Arduino, Sensor Fingerprint, Sensor Ultrasonik dan Sidik Jari.
\end{abstract}

Abstract - In door security systems, many have used, even more sophisticated, but with sophistication or a better security system but there are also drawbacks, namely the cost to implement it is very expensive. Therefore we need a door security system which is cheaper and more affordable in its implementation. In this research, the writer raises a case that is making a door security system that can be applied and affordable in operational costs. This door security system uses the Arduino application as an uploader, then a fingerprint sensor and an ultrasonic sensor as the tools used. This door security system can only be implemented if this system is supplied with electricity and can only be accessed against registered fingerprints.

Keywords - Door Security System, Arduino Application, Fingerprint Sensor, Ultrasonic Sensor and Fingerprint.

\section{Pendahuluan.}

\section{A. Latar Belakang}

Keamanan rumah atau ruangan merupakan suatu hal yang sangat penting untuk diperhatikan dan untuk menciptakan keamanan tersebut, banyak hal yang dapat kita lakukan salah satunya adalah pemanfaatan teknologi dalam menjaga keaman rumah atau ruangan, karena sering kali terjadi pembobolan toko atau rumah pada saat pemilik toko atau pemilik rumah sedang tidak ada ditempat. Untuk menjaga barang penting yang ada diruangan atau didalam rumah sudah seharusnya dijaga seaman mungkin dalam menjaganya dan itu bisa dilakukan menggunakan sistem keamanan pintu dengan menggunakan berbagai macam cara, adapun dengan menggunakan kunci konvesional atau dengan menggunakan kunci yang memanfaatkan kartu Radio Frequency Identification (RFID) dan menggunakan sistem keamanan pintu dengan sensor fingerprint.

Pengamanan dengan menggunakan kunci konvensional yang banyak digunakan oleh masyarakat mudah sekali dilumpuhkan oleh pelaku tindak kejahatan. Selain itu dengan menggunakan kunci konvensional dalam sistem pengamanan juga kurang terpecaya karena kunci konvensional mudah hilang dalam pengunaannya, sehingga sistem ini dirasa kurang praktis dan rentang terhadap tindakan pencurian [1].

Adapun keunggulan dari sistem keamanan ini yaitu dari desain atau proses alat tersebut berjalan. Dari sistem ini dilengkapi juga dengan selenoid doorlock sebagai pengunci pintu dan pembuka kuncinya. Dan alat ini didesain unutuk di aplikasikan di bagian belakang pintu, jadi pintu akan terkunci dari dalam, di bagian depan pintu hanya sensor ultrasonik dan sensor fingerprint saja, maka secara logika sistem keaman pintu ini lebih efektif terhadap tindak kejahatan dalam arti pembobolan pintu secara paksa. Adapun komponen terpenting dalam sistem ini adalah arduino uno $\mathrm{r}$, sensor fingerprint dan sensor ultrasonik.

Dengan kemajuan dibidang ilmu pengetahuan dan teknologi, mendorong manusia untuk terus melakukan perkembangan ilmu pengetahuan dan teknologi (IPTEK). Salah satu dari kemajuan dibidang teknolgi adalah sistem keamanan yang memanfaatkan teknologi yang ada. Sistem keamanan tersebut berfungsi unutuk menunjang peningkatan suatu keaman dokumen atau barang-barang penting lainnya dalam suatu ruangan. Berdasarkan uraian latar belakang diatas maka penulis membuat alat yang berjudul "SISTEM KEAMANAN 
PINTU BERBASIS ARDUINO UNO R3 ATMEGA 328P MENGGUNAKAN FINGERPRINT DAN ULTRASONIK".

\section{B. Identifikasi Masalah}

Berdasarkan latar belakang permasalahan diatas, maka penulis mengidentifikasi masalah sebagai berikut:

1) Sistem keamanan masih menggunakan sistem lama yaitu masih menggunakan kunci konvensional dimana sistem ini mudah sekali untuk dibobol.

2) Sistem keamanan kunci konvesional ini juga mudah untuk diduplikat terhadap anak kuncinya.

3) Pembobolan terhadap sistem kunci konvesional ini banyak caranya seperti dengan memotong pengait besi pada gembok kunci dan bisa juga dengan memaksa merusak pada lubang gembok tersebut.

4) Adapun sistem keamanan lainnya yaitu dengan menggunakan sistem digital yang memanfaatkan kartu Radio Frequency Identification (RFID) namun sistem ini sangat pekat terhadap gelombang radio dan data pada kartu tersebut dapat hilang sehingga tidak dapat digunakan kembali.

\section{Batasan Masalah}

Batasan yang dimaksudkan untuk membatasi ruang lingkup pembahasan agar alat yang dibuat lebih terarah. Adapun batasan masalah tersebut adalah :

1) Membuka pintu dengan sidik jari.

2) Sensor ultrasonik hanya dapat mendeteksi di jarak maksimal 4 meter dan di tinggi di kisaran 1,1 meter smpai 1,3 meter.

3) Meminimalisir dalam mengakses dan membuka pintu.

4) Sensor fingerprint hanya dapat di akses pada jarak 1 meter dan kecepatan sensor fingerprint dapat membaca di kisaran 0,7 detik.

5) Sensor ultrasonik HC SR 04 hanya dapat mendeteksi di kisaran 0,4 detik.

6) Pengunci pintu meggunakan selenoid doorlock yang dikendalikan dengan boar arduino uno.

\section{Metodologi Pengumpulan Data}

Dalam kegiatan untuk memperoleh data pada penulisan tugas akhir ini, penulis menggunakan teknik pengumpulan data yang digunakan adalah sebagai berikut :

\section{A. Observasi}

Melakukan observasi atau peninjauan tempat sebelum pelaksanaan kegiatan pengumpulan data dengan mengadakan pengenalan terhadap objek tugas akhir, aktivitas kerja dan bahan kajian.

\section{B. Literatur Review}

Melakukan pengumpulan data secara tidak langsung dengan melakukan studi kepustakaan, yaitu dengan mengumpulkan data-data dan teori-teori yang berhubungan dengan penulisan penelitian.

\section{Metode Pengembangan Perangkat Lunak}

Model sequential linier yang meliputi beberapa proses, seperti System Analysis, System Design, System Coding, System Testing.

\section{Gambar 1. Metode Sequential Linier [2]}

Keterangan:

1) Analisis kebutuhan perangkat lunak (System Analysis), proses pengumpulan kebutuhan diinfestasikan dan difokuskan, khususnya pada perangkat lunak. Untuk memahami sifat program yang dibangun, perekayasa perangkat lunak harus memahami

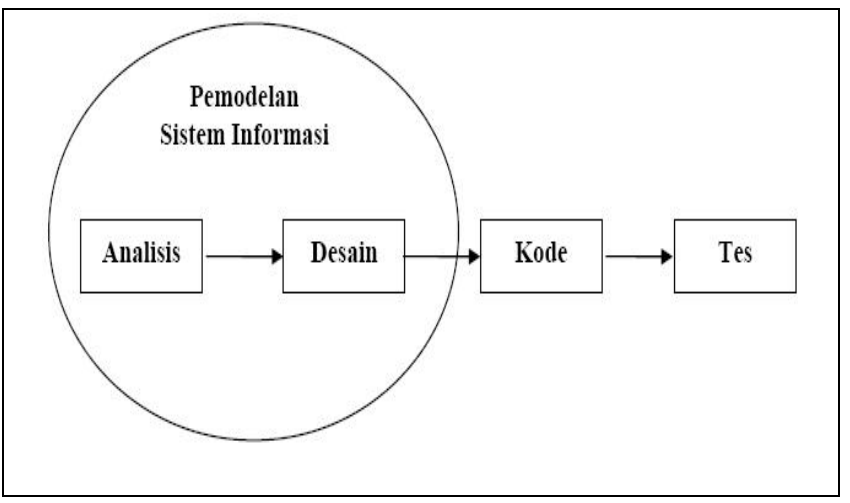

domain informasi, tingkah laku,unjuk kerja, dan antar muka yang di perlukan.

2) Desain, adalah proses multi langkah yang berfokus pada empat atribut sebuah program yang berbeda, struktur data, arsitektur perangkat lunak, representasi interface, dan detail (algoritma) prosedural. Proses desain menerjemahkan syarat/kebutuhan keadaan sebuah representasi perangkat lunak yang dapat diperkirakan demi kualitas sebelum di mulai pemunculan kode.

3) Generasi kode. Desain harus diterjemahkan kedalam bentuk mesin yang biasa dibaca. Langkah pembuatan kode melakukan tugas ini. Jika desain melakukan dengan cara yang lengkap, pembuatan kode dapat diselesaikan dengan mekanis.

4) Pengujian. Proses pengujian berfokus pada logika internal perangkat lunak, memastikan bahwa semua pernyataan telah diuji, dan pada eksternal fungsional yaitu mengarahkan pengujian untuk menemukan kesalahan-kesalahan dan memastikan bahwa input yang dibatasi akan memberikan hasil aktual yang sesuai dengan hasil yang dibutuhkan. Model ini sering disebut siklus kehidupan klasik atau sekuensial linier, merupakan paradigma rekayasa perangkat lunak yang paling tua dan paling banyak dipakai. Model ini juga mengusulkan pendekatan perkembangan perangkat lunak yang sistematik dan sekuensial (tingkat dan kemajuan system pada seluruh analisis, desain, kode, pengujian, dan pemeliharaan). Model pengembangan dalam pembuatan perangkat lunak ini.

\section{LANDASAN TEORI}

\section{A. Pengertian Biometric}

Teknologi biometric adalah sistem yang menjembatani kebutuhan tersebut dengan menggunakan bagian tubuh manusia sebagai kepastian pengenalan. Bagian tubuh manusia 
yang digunakan antara lain sidik jari, mata dan wajah seseorang. Teknologi biometric merupakan teknologi yang digunakan untuk menunjukkan keaslian (authentication) dari individu yang melakukan akses terhadap aset organisasi. Authentication adalah konsep yang menunjukkan bahwa hanya mereka yang diijinkan saja (authentic) yang dapat mempunyai akses terhadap aset organisasi atau hal hal yang bersifat konfidential lainnya. Biometric juga bisa didefunisikan sebagai studi untuk mengenali seseorang secara unik. Didukung faktor harga yang semakin terjangkau dan bisa diterapkan pada banyak sektor, teknologi ini akan menggusur kata sandi (password) ataupun kartu (misal credit card) sebagai alat autentikasi maupun identifikasi. Kemajuan pesat dalam jaringan komunikasi mapun mobilitas alat memang membutuhkan [3].

\section{B. Mikrokontroler}

Mikrokontroler merupakan sebuah processor yang digunakan untuk kepentingan kontrol. Menskipun mempunyai bentuk lebih kecil dari komputer pribadi dan mainframe, mikrokontroler dibangun dengan dengan elemen - elemen yang sama. Mikrokontroler adalah alat yang mengerjekan intruksi intruksi yang diberikan, artinya bagian utama dari suatu sistem otomatis/terkomputerisasi adalah program didalamnya yang dibuat oleh programmer. Perogram mengintruksikan mikrokrontroler untuk melakukan jalinan yang panjang dari aksi - aksi sedrhana untuk melakukan tugas yang lebih kompleks sesuai keinginan programmer [4].

\section{Arduino Uno R3}

Arduino adalah kit elektronik atau papan rangkaian elektronik open source yang di dalamnya terdapat komponen utama, yaitu sebuah chip mikrokontroler dengan jenis AVR dari perusahan Atmel. Mikrokontroler itu sendiri adalah chip atau IC (integrated circuit) yang bisa di program menggunakan komputer. Tujuan menanamkan program pada mikrokontroler adalah agar rangkaian elektronik dapat membaca input, memproses input tersebut dan kemudian menghasilkan output sesuai yang diinginkan. Jadi mokrokontroler bertugas sebagai otak yang mengendalikan input, proses dan output sebuah rangkaian elektronik [5].

\section{Sensor Fingerprint}

Sebuah sistem fingerprint scanner memiliki dua pekerjaan, yakni mengambil gambar sidik jari pengguna, dan memutuskan apakah pola alur sidik jari dari gambar yang diambil sama dengan pola alur sidik jari yang ada di database. Fingerprint adalah sebuah perangkat elektronik yang digunakan untuk menangkap gambar digital dari pola sidik jari [6]. Ada beberapa cara untuk mengambil gambar sidik jari seseorang, namun salah satu metode yang paling banyak digunakan saat ini adalah optical scanning. Inti dari scanner optical adalah Charge Coupled Device(CCD). Proses scan mulai berlangsung saat seseorang meletakkan jari pada lempengan kaca dan sebuah kamera CCD mengambil gambarnya. Scanner memiliki sumber cahaya sendiri, biasanya berupa larik light emitting diodes (LED), untuk menyinari alur sidik jarinya. Sistem CCD menghasilkan gambar jari yang terbalik, area yang lebih gelap merepresentasikan lebih banyak cahaya yang dipantulkan (bagian punggung dari alur sidik jari), dan area yang lebih terang merepresentasikan lebih sedikit cahaya yang dipantulkan (bagian lembah dari alur sidik jari).

\section{E. Sensor Ultrasonik}

Di dalam dunia elektronika kita mengenal berbagai macam sensor dan tranduser. Sensor ultrasonik atau dinamakan sensor sonar adalah sesnsor yang menggunakan suara ultrasonik untuk menditeksi suatu objek yang ada dihadapannya dan dapat digunakan menghitung jarak terhadap objek tersebut. sensor ultrasonik tipe HC-SR04. Bekerja pada tegangan 5V DC dengan arus $15 \mathrm{~mA}$. Jarak maksimal pengukuran 4 meter dan minimal $2 \mathrm{~cm}$, bekerja pada frekuensi $40 \mathrm{~Hz}$ dan dapat langsung dihubungkan dengan minimum sistem mikrokontroler menggunakan kabel pita [7].

Pengertian sensor ultrasonik lainnya adalah sensor ultrasonik adalah sebuah sensor yang memiliki fungsi untuk mengubah besaran fisis alias bunyi menjadi besaran listrik, begitupun sebaliknya. Prinsip kerja sensor ultrasonik ini cukup simpel, yakni berdasarkan pantulan suatu gelombang suara sehingga dapat digunakan untuk mendefiniskan eksistensi atau jarak suatu benda dengan kecepatan membaca 0,7 detik. Karena sensor ini menggunakan gelombang ultrasonik. Gelombang ultrasonik sendiri memiliki frekuensi yang sangat tinggi, mencapai $20.000 \mathrm{~Hz}$ yang tidak bisa didengar oleh telinga manusia.

\section{HASIL DAN PEMBAHASAN}

\section{A. Perancangan Diagram Blok}

Rancangan diagram blok rangkaian menggambarkan rancangan komponen dan alat yang digunakan pada sistem. Rancangan diagram blok rangkaian dapat dilihat pada gambar 2 pada gambar tersebut terdapat bagian utama, yaitu bagian input, bagian proses, bagian output, dan bagian pengantar arus listrik.

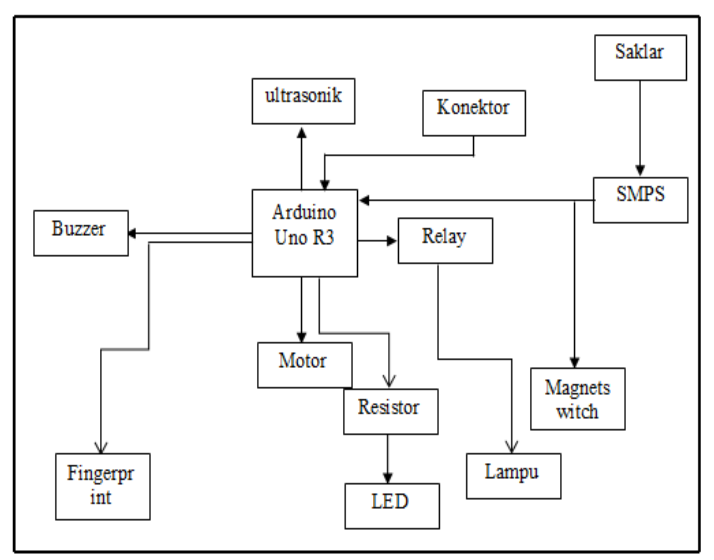

Gambar 2. Rancangan Blok Diagram

\section{B. Perancangan dan Implementasi Sistem}

Perancangan sistem adalah strategi untuk memecahkan masalah dan mengembangkan solusi terbaik bagi permasalahan itu. Perancangan sistem adalah termasuk bagaimana mengorganisasi sistem ke dalam subsistem, serta alokasi subsistem-subsistem ke komponen-komponen perangkat keras, perangkat lunak serta prosedur-prosedur.

Tujuan perancangan sistem untuk memenuhi kebutuhan pemakaian sistem (user). Untuk memberikan gambaran yang 
jelas dan menghasilkan rancangan bangun yang lengkap kepada pemograman komputer dan ahli-ahli teknik lainnya yang terlibat dalam pengembangan atau pembuatan sistem. Perancangan flowchat dapat dilihat gambar dibawah ini:

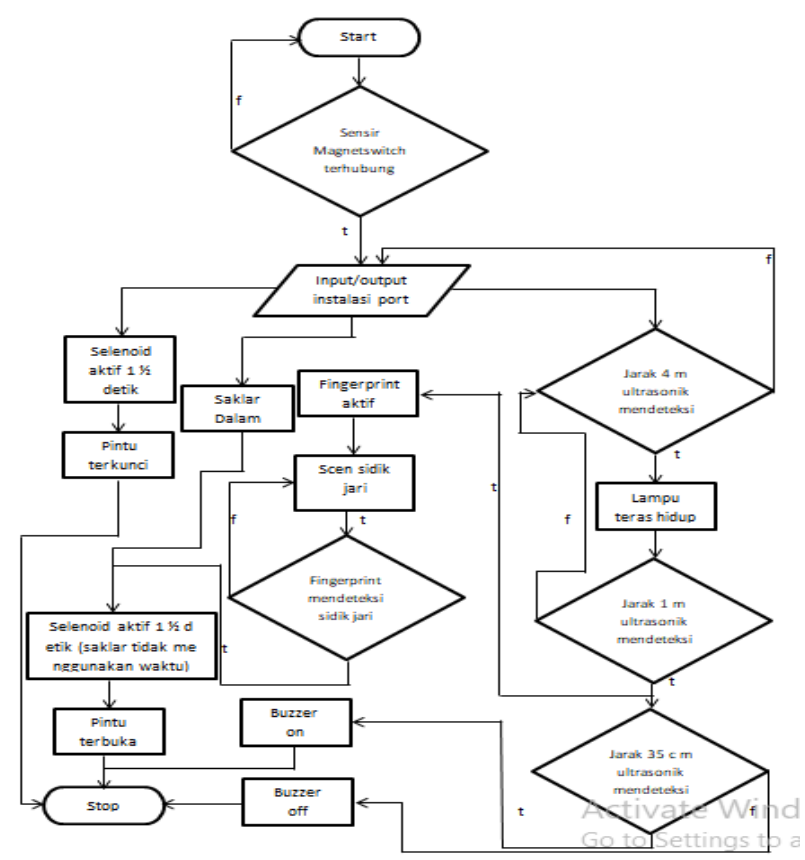

Gambar 3. Perancangan Flowcart

\section{Perancangan Sistematika}

Rangkaian sistematika perangkat merupakan rangkaian keseluruhan dari rangkaian-rangkaian komponen yang telah dirancang terlebih dahulu. Rangkaian ini menggabungkan komponen sesnsor ultrasonik, sensor fingerprint, selenoid doorlock, sensor magnetswitch, relay, lampu, saklar, power supplay, led, resistor dan buzzer dengan arduino uno sebagai sistem kendali Tampilan keseluruhan rangkaian terdapat pada gambar 4 dibawah ini.

Didalam pembuatan perancangan sistematika ini yaitu menggunakan aplikasi proteus, dimana aplikasi ini hanya menyediakan beberapa komponen saja. Jadi dalam pembuatan perancangan sistematika ini ada beberapa yang harus menggunakan koponen lain atau sebagai pengganti dalam sistematika elektrikalnya saja.

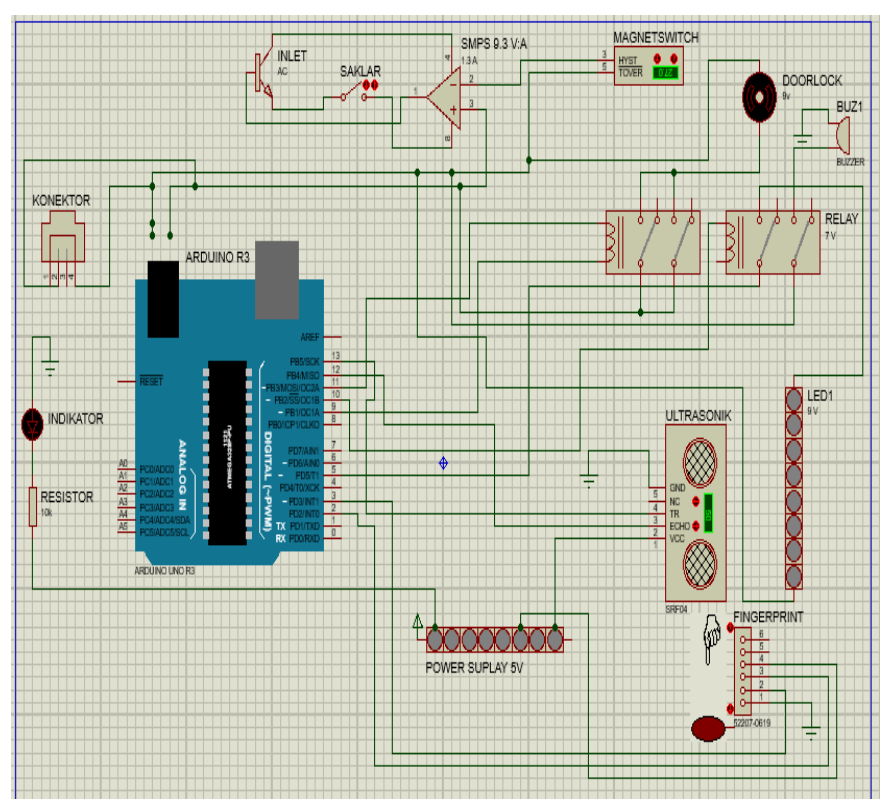

\section{Gambar 4. Perancangan Sistematik}

\section{Perancangan Media Prototype}

Perancangan media prototype ini adalah bahan yang digunakan untuk membuat media prototype, media prototype ini menggunakan bahan triplek tipis yang dibentuk atau dipotong menjadi 3 bagian, yaitu: daun pintu, kusen pintu dan alas pintu. Dimana 3 bagian ini menjadi media prototype yang terbuat dari triplek, adapun bagian lainnya yang terbuat dari kotak bekas yang terbuat dari karton yang dijadikan media sebagai kotak $p c b$, rellay dan smps. Berikut gambar 5 media prototype:

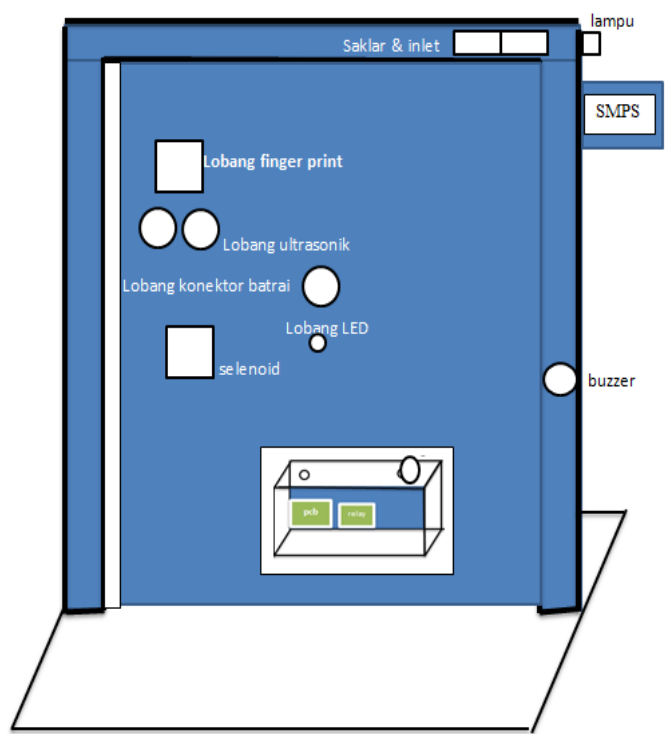

Gambar 4. Prototype Pintu dan Peletakkan Komponen

\section{E. Implementasi Rangkaian Sistematik}

Rangkaian sistematika perangkat merupakan rangkaian keseluruhan dari rangkaian-rangkaian komponen yang telah dirancang terlebih dahulu. Rangkaian ini menggabungkan komponen sesnsor ultrasonik, sensor fingerprint, selenoid doorlock, sensor magnetswitch, relay, lampu, saklar, power 
supplay, led, resistor dan buzzer dengan Arduino Uno sebagai sistem kendali Tampilan keseluruhan rangkaian terdapat pada gambar 5 dibawah ini.

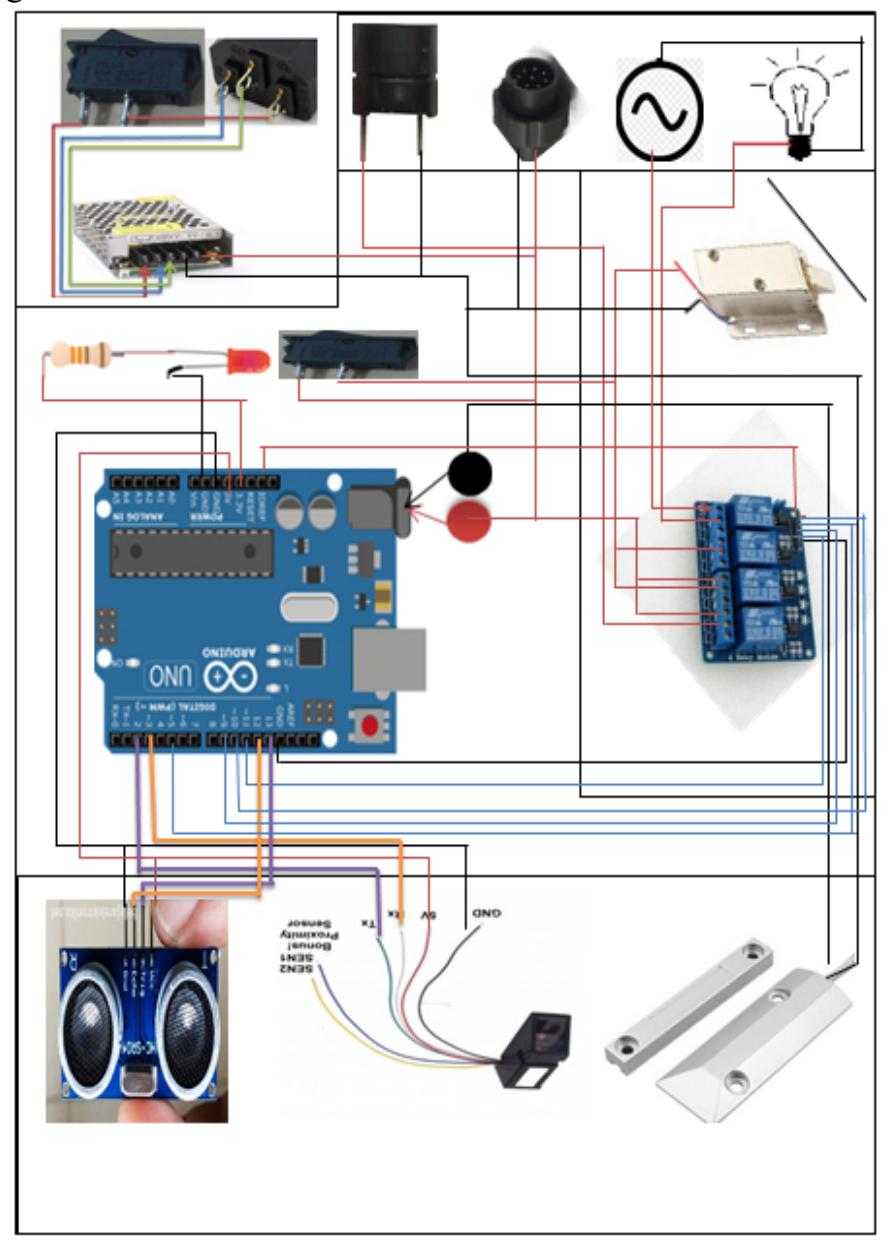

Gambar 4. Rangkaian Electrical Drawing

\section{F. Implementasi Media Prototype}

Berikut hasil dari desain media prototype yang sudah di implementasikan dan sudah dipasang atau di instal bersama komponennya. Dimana media prototype ini dibagi menjadi dua bagian, yaitu bagian tampilan depan dan bagian tampilan belakang.

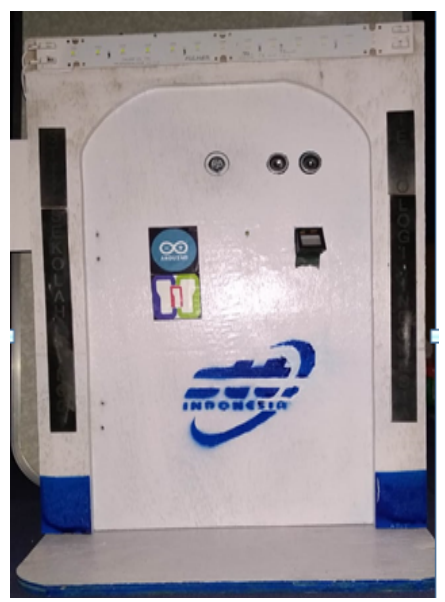

Gambar 5. Tampilan Bagian Depan Pintu

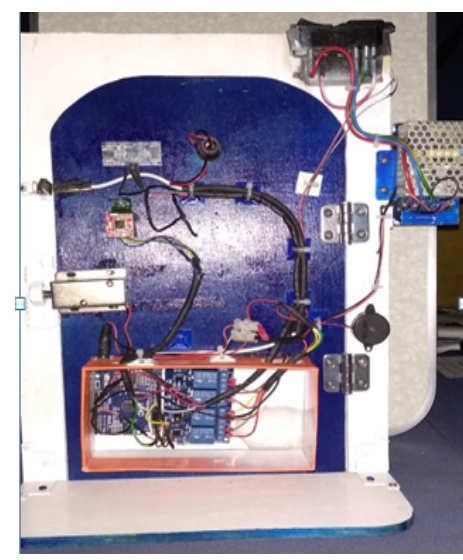

\section{Gambar 6. Tampilan Bagian Belakang Pintu}

\section{KESIMPULAN}

Berdasarkan hasil pengujian yang telah dilakukan terhadap prototype sistem kemamanan pintu berbasis arduino uno r3 atmega 328p menggunakan fingerprint dan ultrasonik, maka dapat disimpulkan sistem tersebut sebagai berikut:

1) Pada saat pintu tertutup rapat maka pintu dapat terkunci secara otomatis.

2) Sensor ultrasonik dapat membaca benda atau orang pada jarak kurang dari 4 meter, sehingga lampu teras, sensor fingerprint dan buzzer dapat dikendalikan (aktif).

3) Sensor fingerprint dapat membaca sidik jari sehingga kunci pintu dapat terbuka secara otomatis.

4) Sensor magnetswitch dapat membaca atau menghubungkan arus ke arduino pada saat pintu tertutup saja.

5) Semua komponen dapat berfungsi sebagai mana yang telah dirancang dan diharapkan.

\section{REFERENSI}

[1] Akbar Iskandar, Muhajirin, Lisah, Sistem Keamanan Pintu Berbasis Arduino Mega, Makasar : Jurnal Informatika UPGRIS, Vol. 3, No. 2, 2017.

[2] Verdi Yasin, Rekayasa Perangkat Lunak Berorientasi Objek, Jakarta : Mitra Wacana Media, 2012.

[3] Andika D.L. Tumuli, Xaverius N. Najoan, Alwin M. Sambul, Implementasi Teknologi Biometrical Identification untuk Login Hotspot, Sulawesi : E-Journal Teknik Informatika, Vol. 12, No. 1, 2017.

[4] Eka Permana, Ridwan Hidayat, Rancang Bangun Sistem Keamanan Rumah Berbasis SMS Gateway Menggunakan Mikrokontroler, Jawa Barat : Jurnal Teknologi Informasi dan Komunikasi, Oktober. 2017.

[5] Julkifli Muksin, ddk, Sistem Kontrol Suhu dan Pendeteksi Gerakan Pada Ruangan Laboratorium Berbasis Arduino Uno R3 Dengan Modul Real Time Clock (RTC) dan Passive Infrared Receiver (PIR), ILKOMINFO, Ternate : ILKOMINFO, Vol. 4, No.1. 2021.

[6] Joni Tappi, ddk, Rancang Bangun Perangkat Kendali Pintu Rumah Menggunakan Fingerprint Berbasis Arduino Leonardo, Kalimantan Utara : Journal of Applied Microcontrollers and Autonomous System, Vol. 4, No.1, Juni. 2018.

[7] Rochmad Adi S.P, Ba,bang Suprianto, Pengembangan Trainer Mikrokontrol Berbasis Atmega16 Dengan Menerapkan Aplikasi Kit Sensor Ultrasonic dan Kit Sensor Infra Red Sebagai Media Pembelajaran Pada Mata Pelajaran Teknik Mikroprosessor Di SMK Negeri 3 Surabaya, Surabaya : Jurnal Pendidikan Teknik Elektro, Vol. 05, No. 1. 2016. 